\title{
CHARACTERIZATION OF LEACHATE FROM PANCHANG BEDENA LANDFILL, BATANG PADANG LANDFILL AND MATANG LANDFILL: A COMPARATIVE STUDY
}

\section{Nor Nazrieza M.S.", Siti Rohana M.Y., Subramaniam K., Hazilia H., Amir Herberd A.}

Universiti Teknologi MARA, Kampus Puncak Alam 42300 Bandar Puncak Alam, Selangor, Malaysia. *Corresponding author: nornazrieza@yahoo.com

\begin{abstract}
A Landfill is the main disposal method of solid waste in Malaysia but this creates issues due to its leachate generation. Improper leachate treatment pollutes the environment and is harmful to human health. This study aims to determine the characteristics of landfill leachate from three landfills sites that differs in age and types; Panchang Bedena Landfill (PBL), Batang Padang Landfill (BPL) and Matang Landfill (ML). The parameters tested in this study include $\mathrm{pH}$, temperature, suspended solid (SS), chromium hexavalent, $\mathrm{BOD}_{5} \mathrm{COD}$, copper, lead and cadmium. Analysis was carried out with standard methods using HANNA HI 9828 Portable Multiparameter, atomic absorption spectrophotometer and portable spectrophotometer, HACH DR2800. The mean values of the parameters from PBL, BPL and $\mathrm{ML}$ are $\mathrm{pH}\left(8.60,7.67\right.$ and 6.76), temperature $\left(29.30,33.02\right.$ and $\left.29.47{ }^{\circ} \mathrm{C}\right)$, chromium hexavalent (0.030, 0.007 and $0.020 \mathrm{mg} / \mathrm{L})$, SS (101.7, 127.3 and $45.0 \mathrm{mg} / \mathrm{L}), \mathrm{BOD}_{5}(106.70,144.07$ and 100.30 $\mathrm{mg} / \mathrm{L}), \operatorname{COD}(153.7,1418.0$ and $257.5 \mathrm{mg} / \mathrm{L}), \mathrm{BOD}_{5} / \mathrm{COD}(0.69,0.09$ and $0.39 \mathrm{mg} / \mathrm{L})$, copper $(0.24,1.52$ and 0.10 $\mathrm{mg} / \mathrm{L})$, lead $(1.95,0.75$ and $0.13 \mathrm{mg} / \mathrm{L})$ and cadmium $(0.03,0.001$ and $0.003 \mathrm{mg} / \mathrm{L})$, were recorded, respectively. The obtained results were compared to the standard limit under the Environmental Quality (Control of Pollution from Solid Waste Transfer Station and Landfill) Regulation 2009. The leachate quality from PBL has the highest range of heavy metals, followed by BPL and ML which is due to landfill age. However, BPL shows greater organic contaminants such as $\mathrm{SS}, \mathrm{BOD}_{5}$ and $\mathrm{COD}$ which may be due to the absence of leachate aeration facilities at the landfill site compared to PBL and ML. A proper treatment strategy is crucial to reduce the pollutants before being discharged into the water bodies.
\end{abstract}

\begin{abstract}
ABSTRAK Tapak pelupusan adalah kaedah pelupusan utama sisa pepejal di Malaysia tetapi ini mewujudkan isu penghasilan air larut resap. Rawatan air larut resap yang tidak cekap akan mencemarkan alam sekitar dan membahayakan kesihatan manusia. Kajian ini bertujuan untuk menentukan ciri-ciri air larut resap dari tiga tapak pelupusan sampah yang berbeza tempoh operasi dan kategori; tapak pelupusan Panchang Bedena (PBL), tapak pelupusan Batang Padang (BPL) dan tapak pelupusan Matang (ML). Parameter yang diuji dalam kajian ini termasuk $\mathrm{pH}$, suhu, pepejal terampai (SS), kromium heksavalen, permintaan oksigen biokimia (BOD5), permintaan oksigen kimia (COD), kuprum, plumbum dan kadmium. Analisis telah dijalankan dengan menggunakan HANNA HI 9828 Multiparameter mudah alih, spektrofotometer penyerapan atom dan spektrofotometer mudah alih, HACH DR2800. Nilai purata parameter dari PBL, BPL dan ML adalah pH (8.60, 7.67 dan 6.76), suhu (29.30, 33.02 dan 29.47 $\left.{ }^{\circ} \mathrm{C}\right)$, kromium heksavalen (0.030, 0.007 dan $0.020 \mathrm{mg} / \mathrm{L})$, SS (101.7, 127,3 dan 45.0 mg/L), BOD 5 (106.70, 144.07 dan $100.30 \mathrm{mg} / \mathrm{L})$, COD (153.7, 1418.0 dan $257.5 \mathrm{mg} / \mathrm{L})$, BOD5/COD (0.69, 0.09 dan 0.39 mg/L), kuprum (0.24, 1.52 dan $0.10 \mathrm{mg} / \mathrm{L})$, plumbum $(1.95,0.75$ dan $0.13 \mathrm{mg} / \mathrm{L})$ dan cadmium $(0.03,0.001$ dan $0.003 \mathrm{mg} / \mathrm{L})$, masing-masing dicatatkan. Keputusan yang diperolehi dibandingkan dengan had piawaian Peraturan Kualiti Alam Sekeliling (Kawalan Pencemaran daripada Stesen Pemindahan Sisa Pepejal dan Kambus Tanah) Peraturan 2009. Kualiti air larut resap dari PBL mencatatkan julat tertinggi untuk logam berat, diikuti oleh BPL dan ML yang disebabkan oleh usia tapak pelupusan. Walau bagaimanapun, BPL menunjukkan bahan cemar organik yang lebih tinggi seperti SS, BOD5 dan COD yang mungkin disebabkan oleh ketiadaan kemudahan fasiliti pengudaraan di kolam air larut resap berbanding dengan PBL dan ML. Strategi rawatan yang betul adalah penting untuk mengurangkan bahan pencemar sebelum dilepaskan ke dalam sumber air.
\end{abstract}

(Keywords: Leachate, Characteristics, Parameters)

\section{INTRODUCTION}

The generation of wastes is increasing each year. As a country that's focusing more towards industrialization, Malaysia cannot escape from population expansion that changes consumption pattern which will then lead to higher waste generation [1]. In order to manage its wastes,
Malaysia opted for the landfill method which has been the primary disposal method in various countries [2] including Malaysia [3-5]. Landfills are considered the most widely practiced method for disposal of Municipal Solid Waste (MSW), taking in up to $95 \%$ total MSW collected worldwide [6,7]. At present, landfilling is the only method used for MSW disposal in Malaysia, most of which practices 
the open dumping method that can pose serious environmental and social threats. This is due to the production of leachate that had become a major environmental problem [8]. Chronic production of toxic leachate can contain high concentrations of organic compounds as well as pathogens. Coupled with the slow degradation of waste mass, this two factors posed a long-term environmental and health risk which are a major concern when discussing conventional landfill method [9]. The leachates are discharged directly into water courses without any treatment, thus threatening the surrounding ecosystem, particularly in cases where landfills are located upstream from water intakes [5]. Regadio [10] mention that the potential pollution caused by leachates is the result of several factors, including the release of ammonia, chlorinated and nonchlorinated organic compounds and heavy metal ions into the environment, all of which are toxic to living organisms. Therefore, the main purpose of this research is to study the characteristics of landfill leachate in three landfills in Peninsular Malaysia, namely, Panchang Bedena Landfill
(PBL), Batang Padang Landfill (BPL) and Matang Landfill (ML). The identification of environmental risks of these sites was performedvia comparison with Environmental Quality (Control of Pollution from Solid Waste Transfer Station and Landfill) Regulations 2009 under the Laws of Malaysia Environmental Quality Act (EQA) 1974. This study attempts to provide baseline data on the characteristics of landfill leachate and the level of the pollutants.

\section{MATERIALS AND METHOD}

\section{Site Characteristics}

The three different sites were chosen based on the different age of landfill sites and also types of landfill and the available facilities. The age of landfill is characterized by the duration of time the landfills were actively utilized. The characterizations of leachate from these three sites were compared. Summary of landfill site characteristics is indicated in Table 1.

Table 1. Site characteristics

\begin{tabular}{lll}
\hline $\begin{array}{l}\text { Panchang Badena landfill } \\
\text { (PBL) }\end{array}$ & Batang Padang Landfill (BPL) & Matang Landfill (MT) \\
\hline $\begin{array}{l}\text { Lot 280, 281, Mukim Panchang } \\
\text { Badena, 45300 Sungai Besar, }\end{array}$ & $\begin{array}{l}\text { Kampung Panderas Slim Village, } \\
\text { Selangor }\end{array}$ & Near Taiping Town, Perak \\
10 acres & 7.59 acres & \\
Unsanitary landfill (with leachate & $\begin{array}{l}\text { Unsanitary landfill (without } \\
\text { leachate aeration) }\end{array}$ & $\begin{array}{l}\text { Sanitary landfill (Improved } \\
\text { anaerobic landfill) }\end{array}$ \\
aeration) & Class I non sanitary landfill & Level 3 for sanitary lanfill \\
Have been operated more than 10 & $\begin{array}{l}\text { Have been operated more than 30 } \\
\text { years }\end{array}$ & $\begin{array}{l}\text { Have been operated more than } \\
14 \text { years }\end{array}$ \\
years & $\begin{array}{l}120-150 \text { tons of waste received } \\
\text { daily }\end{array}$ & $\begin{array}{l}300 \text { tons of waste received } \\
\text { daily }\end{array}$ \\
\hline
\end{tabular}

a.Panchang Bedena Landfill.

The study site for this project was conducted at Lot 280, 281, Mukim Panchang Bedena, 45300 Sungai Besar, Selangor which is an active 10 acres landfill located in Sabak Bernam, Malaysia. The coordination of this landfill is $3^{\circ} 41^{\prime} 23.97^{\prime} \mathrm{N}$, $100^{\circ} 57^{\prime} 46.60^{\prime \prime} \mathrm{E}$. This is an improved anaerobic unsanitary landfill with leachate retention pond facilities with forced aeration. This landfill has been in operation for more than 10 years. According to classification on non sanitary landfill in Malaysia by Fauziah [11], this landfill is classified as class
III, with Class II facilities, in addition to leachate recirculation system that allows the collection, recirculation and monitoring of landfill leachate (Table 2).

\section{b.Batang Padang Landfill.}

Batang Padang Municipal Solid Waste Landfill is located in Kampung Panderas Slim Village, Perak. Distance from the town of Slim River and Tanjong Malim is approximately $23 \mathrm{~km}$ and 28 $\mathrm{km}$, respectively. This site occupies an area of 7.59 of acres. An estimated 120-150 tons of municipal 
solid wastes were disposed at Batang Padang MSW landfill per day. The landfill is fully maintained by the local authority and who their operation more than 30 years ago without the provision of any leachate treatment. This landfill is classified as unsanitary landfill, also known as open dumping. Based on Table 2, this is a class I non sanitary landfill, with minimal infrastructure.

\section{c.Matang Landfill.}

ML is located at $4^{\circ} 49^{\prime} 20.08^{\prime \prime} \mathrm{N}$ and $100^{\circ}$ 40'44.08'E near Taiping in Perak, Malaysia. ML has been operated for more than 14 years with the total landfill area of $12 \mathrm{ha}$, approximately 29.65 acres. The landfill receives about 300 tons of solid waste daily. Matang landfill has been upgraded to a new aerobic sanitary landfill. ML is equipped with a leachate collection pond, however, there is no further treatment for the leachate except for forced aeration. This landfill is classified as an improved aerobic landfill and falls under level 3 for sanitary landfill (Table 3).

The Malaysian Government by the Department of Local Government under the Ministry of Housing and Local Government has published a guideline with an updated version on August 2006 which is "The Technical Guideline for Sanitary Landfill, Design and Operation", (MHLG, 2006). The purpose of this guideline is to develop a better landfill site in Malaysia with proposed countermeasures that merge local and foreign innovation and technologies.

However, at present, there are 330 solid waste disposal facilities in Malaysia, of which 291 are municipal solid waste controlled dumps, also known as non sanitary landfill. There are only 12 sanitary landfills recorded, including the Air Hitam sanitary landfill which has already been closed [11]. The summary of municipal solid waste disposal sites in Malaysia is presented in Table 4.

Table 2. Classification of non-sanitary landfills in Malaysia [11].

\begin{tabular}{|c|c|}
\hline Non sanitary landfill class & Facilities \\
\hline $\bar{I}$ & Minimum infrastructure such as fencing and perimeter drains \\
\hline II & $\begin{array}{l}\text { Class I facilities, in addition to gas removal system, separate } \\
\text { unloading and working area, daily cover and enclosing bund } \\
\text { (divider constructed as the embankment of different waste cells), } \\
\text { elimination of informal scavenging and provision of environmen- } \\
\text { tal protection facilities }\end{array}$ \\
\hline III & $\begin{array}{l}\text { Class II facilities, in addition to leachate recirculation system } \\
\text { allowing the collection,recirculation and monitoring of landfill } \\
\text { leachate }\end{array}$ \\
\hline IV & Class III facilities, in addition to a leachate treatment system \\
\hline
\end{tabular}

Table 3. Levels of sanitary landfills (MHLG, 2006)

\begin{tabular}{cl}
\hline Level & Description \\
\hline Level 1 & Controlled tipping \\
Level 2 & Sanitary landfill with a bound and daily cover \\
Level 3 & Sanitary landfill with leachate recirculation system \\
Level 4 & Sanitary landfill with leachate treatment facilities \\
\hline
\end{tabular}


Table 4. Estimated number of MSW disposal sites in Malaysia in 2011 [11]

\begin{tabular}{lc}
\hline Status of disposal facilities & Current number \\
\hline Operating controlled dumps & 155 \\
Closed controlled dumps & 136 \\
Sanitary landfills & 12 \\
Total & $\mathbf{3 0 3}$ \\
\hline
\end{tabular}

\section{Leachate Sampling}

The landfill leachate samples used in this study were collected from PBL, BPL and ML. The samples were collected in 1 Liter amber bottles and stored at $4{ }^{\circ} \mathrm{C}$ in laboratory prior to analysis to minimize the biological and chemical reactions. The collection and preservation of samples were done accordance with the Standard Method for the Examination of Water and Wastewater [12]. However, this study is limited by the frequency of samples taken, which was carried out only once for each site. While this may limit the quality of data obtained, this baseline data can be used to estimate or generate hypotheses for future research.

Analysis of Leachate

Temperature and $\mathrm{pH}$ were analyzed insitu using
HANNA HI 9828 Portable Multiparameter, while Atomic Absorption Spectrophotometer was used to analyze lead and cadmium. The concentrations of other chemicals (suspended solid (SS), copper and chromium hexavalent) were identified using portable spectrophotometer, HACH DR2800. Biological oxygen demand $\left(\mathrm{BOD}_{5}\right)$ and chemical oxygen demand (COD) were analyzed using the standard method [13]. The values of the parameters obtained were then compared with Environmental Quality (Control of Pollution from Solid Waste Transfer Station and Landfill) Regulations 2009.

\section{RESULT AND DISCUSSIONS}

The characteristics of landfill leachate at PBL, BPL and ML, and the values for the measured parameters are shown in Table 5.

Table 5.Characteristic of landfill leachate at PBL, BPL and ML

\begin{tabular}{clllll}
\hline Bil & Parameters & $\begin{array}{l}\text { PBL } \\
\text { Mean }(\mathbf{n}=\mathbf{3})\end{array}$ & $\begin{array}{l}\text { BPL } \\
\text { Mean }(\mathbf{n}=\mathbf{3})\end{array}$ & $\begin{array}{l}\text { ML } \\
\text { Mean (n=3) }\end{array}$ & Standards \\
\hline 1 & pH & 8.60 & 7.67 & 6.76 & $6.0-9.0^{*}$ \\
2 & Temperature (oC) & 29.30 & 33.02 & 29.47 & $40^{*}$ \\
3 & Suspended Solid (mg/L) & 101.70 & 127.33 & 45.00 & $50^{*}$ \\
4 & BOD5 (mg/L) & 106.70 & 144.07 & 100.29 & $20^{*}$ \\
5 & COD (mg/L) & 153.70 & 1481.00 & 257.45 & $400^{*}$ \\
6 & BOD5/COD & 0.69 & 0.09 & 0.39 & $* *$ \\
7 & Lead (mg/L) & 1.953 & 0.745 & 0.130 & $0.1^{*}$ \\
8 & Copper (mg/L) & 0.24 & 1.52 & 0.10 & $0.2^{*}$ \\
9 & Chromium Hexavalent & 0.030 & 0.007 & 0.020 & $0.05^{*}$ \\
10 & Cadmium & 0.030 & 0.001 & 0.003 & $0.01^{*}$ \\
\hline Notes : & \multicolumn{5}{|}{} \\
* Environmental Quality (Control of Pollution from Solid Waste Transfer Station and Landfill) \\
Regulation 2009
\end{tabular}




\section{Physical Characteristics (pH, Temperature and Suspended Solid)}

The $\mathrm{pH}$ values of PBL, BPL and ML are 8.60, 7.67 and 6.76 , respectively. The results are consistent with those published by previous authors $[4,14-$ 18]. The $\mathrm{pH}$ values remain within the permissible limit (6.0-9.0) stated in the Environmental Quality (Control of Pollution from Solid Waste Transfer Station and Landfill) Regulations 2009. pH is an essential quality parameter as it influences many biological and chemical processes of the media. Decaying activities of the waste in the landfill site also affect the value of $\mathrm{pH}$ in leachate. In addition, the range of $\mathrm{pH}$ is also affected by the age of the landfill from which it originated from. [8]. During the early phase of landfill reaction, the available oxygen will be consumed by aerobic bacteria. Once the oxygen has been depleted, the anaerobic bacteria will then convert compounds created by aerobic bacteria into acetic, lactic and formic acids and alcohols causing the landfill to become highly acidic. Late acidic phase and early methanogenic phase will increase the value of $\mathrm{pH}[17,19]$. Generally, the $\mathrm{pH}$ of a stabilized leachate is higher than that of a young leachate [5]. The difference could be due to the stabilized leachate that is produced after or during the fermentation of methane; hence the $\mathrm{pH}$ is higher than 7.5 which indicates the short acidic phase and early methanogenic phase [20-22]. The generalized and the changes in leachate is shown in Figure 1.

Temperatures of the leachate during sampling were $29.30,33.02$ and $29.47{ }^{\circ} \mathrm{C}$ for PBL, BPL and ML, respectively. The temperatures aligned with results stated in various other research $[14,16,23]$. These values are within the limit $\left(40^{\circ} \mathrm{C}\right)$ stated in the Environmental Quality (Control of Pollution from Solid Waste Transfer Station and Landfill) Regulations 2009. As the characteristic feature of the climate of Malaysia is uniform temperature, therefore, the temperatures of the samples did not show much variation (Malaysian Meteorological Department, 2012).

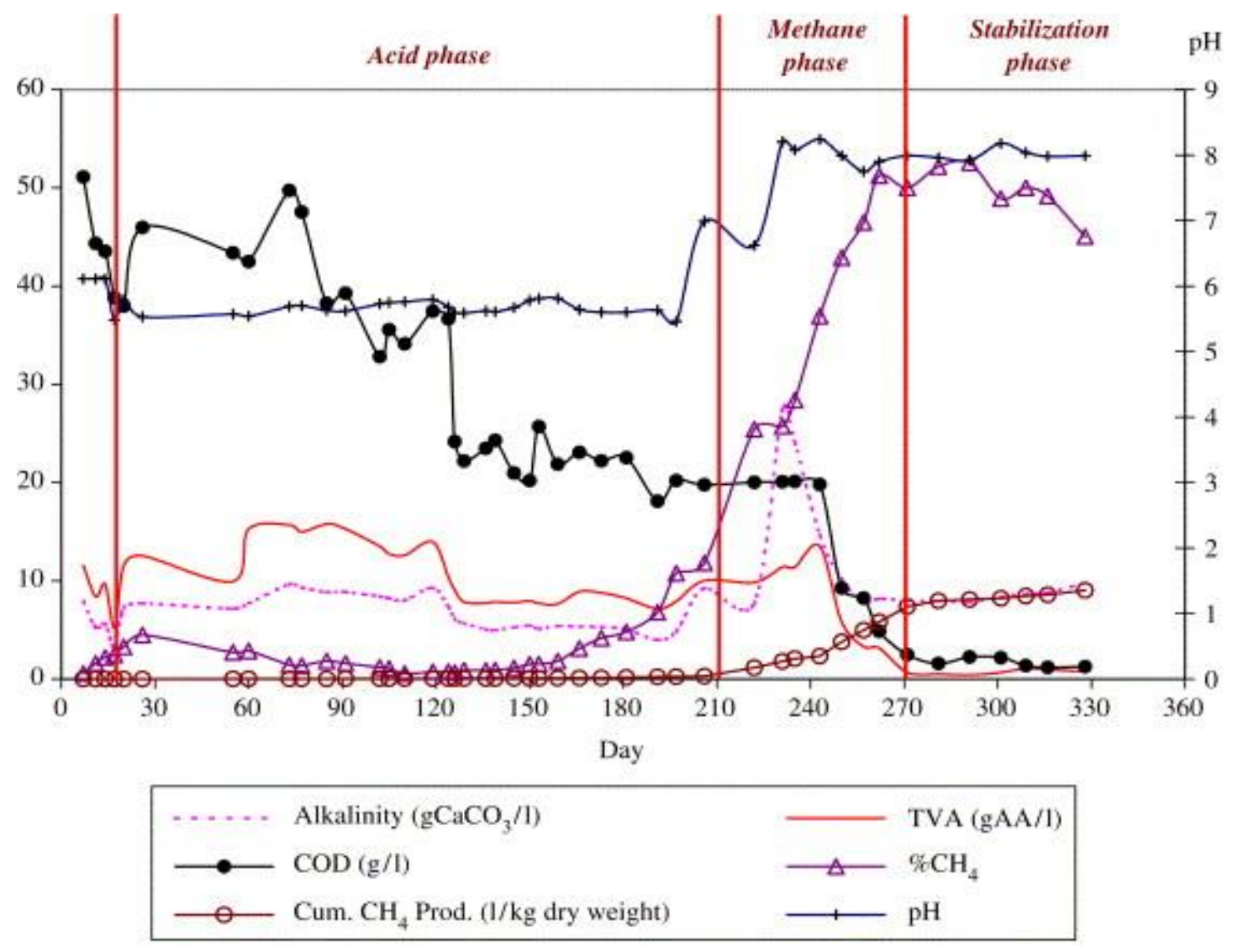

Figure 1. Generalized phases and the changes in leachate, methane composition and production with time of the simulated landfill reactor without leachate recirculation (RC) [19] 
The average values of SS at PBL, BPL and ML were $101.70,127.33$ and $45.00 \mathrm{mg} / \mathrm{L}$, respectively. Results showed that samples from PBL and BPL were higher than the permissible limit $(50 \mathrm{mg} / \mathrm{L})$ set in the Environmental Quality (Control of Pollution from Solid Waste Transfer Station and Landfill) Regulations 2009. Previous research have also found high SS value in leachate sample $[14,15]$. The high turbidity and SS value is mostly associated by the presence of high organic matter with some insoluble form [24]. In addition, there was no treatment carried out for the leachate such as coagulation or flocculation process. In fact, only PBL and ML have the leachate pond with forced aeration. Aeration has an effect of decreasing SS in leachate [5].

\section{BOD $_{5}$}

In this study, the value of $\mathrm{BOD}_{5}$ recorded for each sample of leachate at PBL, BPL and ML were $106.70,144.07$ and $100.29 \mathrm{mg} / \mathrm{L}$, respectively. The measured $\mathrm{BOD}_{5}$ from all sites exceeded the limit $(20 \mathrm{mg} / \mathrm{L})$ set in the Environmental Quality (Control of Pollution from Solid Waste Transfer Station and Landfill) Regulations 2009. High value of $\mathrm{BOD}_{5}$ was also recorded from Kuala Sepetang Landfill as studied by Zainol [14] and in several other research $[5,25]$. It has been reported that the age of the landfill will affect the value of $\mathrm{BOD}_{5}$ with new landfills usually record a range of $\mathrm{BOD}_{5}$ between 2000-30000 mg/L. Conversely, $\mathrm{BOD}_{5}$ for mature landfills usually varies from $100-200 \mathrm{mg} / \mathrm{L}[5,8$, 26]. This is an indication that the landfills are in the methanogenic phase where almost all of the organic compound have been dissolved in the leachate but have yet to complete the stabilization process[27]. Therefore, we made the assumption that the lower value of $\mathrm{BOD}_{5}$ for these landfill sites is due to the operational age of all three landfills that is more than 10 years.

\section{COD}

While the $\mathrm{BOD}_{5}$ value recorded higher than the limit, the COD value, however, was lower than stated in the regulation, with the exception of BPL. Both PBL and ML showed COD values of 153.70 and $257.45 \mathrm{mg} / \mathrm{L}$, respectively while leachate at BPL showed an extremely high COD value of $1481.00 \mathrm{mg} / \mathrm{L}$. The value is at least three times higher than the limit (400 mg/L) by Environmental Quality (Control of Pollution from Solid Waste
Transfer Station and Landfill) Regulations 2009. This staggering difference between BPL and the other two landfills is due to the fact that there is no leachate facilities provided at the BPL landfill site as opposed to the forced aeration carried out at PBL and ML. The higher value of leachate is also contributed by the decomposition process which continuously produce new leachate even though the landfill sites have been in operation for more than 10 years [28]. COD that range between 500 to 4500 $\mathrm{mg} / \mathrm{L}$ can be classified as in the methnogenic phase [29-31]. Stabilized leachates are rich with organic matter [32] such as humic substance (measured as COD intensity) and fulvic like fraction $[8,14]$. The greater values COD were also recorded from Pulau Burung Landfill Site as studied by Bashir [23] and Kuala Sepetang Landfill Site by Zainol [14].

\section{BOD $_{5} /$ COD Ratio}

The values of organic compounds in leachate depend on the different levels of biodegradability of the landfill. The $\mathrm{BOD}_{5} / \mathrm{COD}$ ratio can be considered as a measure of the biodegradability of the organic matter, and hence of the maturity of the leachate and the landfill, which typically decreases with time [6]. The characteristics of landfill stability as a function of $\mathrm{BOD}_{5} / \mathrm{COD}$ ratio are shown in Table 6 . In this study, the $\mathrm{BOD}_{5} / \mathrm{COD}$ ratio for the collected samples were 0.69 (PBL), 0.09 (BPL) and 0.39 (ML). The ratio values indicated that PBL falls within the category of young and unstable landfill while BPL is categorized as an old stable landfill. $\mathrm{ML}$, on the other hand, was categorize as a moderate stable landfill. However, according to the $\mathrm{BOD}_{5} /$ COD ratio in Table 6, the COD values recorded by Zainol [14], KLS and KSLS leachates showed higher biodegradability (0.19 and 0.24$)$ indicating that both leachates are partially stabilized leachates $\left(0.1<\mathrm{BOD}_{5} / \mathrm{COD}<0.3\right)$ rather than stabilized leachate $\left(\mathrm{BOD}_{5}<0.1\right)$, even though the age of both landfills are already more than 10 years old. This study also showed the same pattern as recorded by Zainol [14]. The higher $\mathrm{BOD}_{5} / \mathrm{COD}$ ratio is probably occurred because the landfills are still operating and producing young leachates which are mixed together with old leachates thus increasing its biodegradability [28]. Therefore, biological degradation is still occurring in these landfills [33]. SS, turbidity, colour and COD leachates are possibly related to the landfill age since the characteristics and constituents of leachates depend on this factor. 
Leachates undergo four phases of change according to the age of the landfill, including transition (0-5 years), acid formation (5-10 years), methanogenic phase (15-20 years), and final maturation ( $>$ than 20 years) [5]. The variation of the values could also be due to climate condition, landfill design, site characteristics, solid waste composition and landfill age [34].

\section{Heavy Metals (Lead, Copper, Chromium Hexavalent and Cadmium)}

The values of lead from all samples exceeded the standard limit $(0.1 \mathrm{mg} / \mathrm{L})$ as stated in Environmental Quality (Control of Pollution from Solid Waste Transfer Station and Landfill) Regulations 2009. The values of copper were $0.24,1.52$ and $0.10 \mathrm{mg} / \mathrm{L}$ for PBL, BPL and ML, respectively. Based on the regulation, the values of copper from $\mathrm{PBL}$ and $\mathrm{BPL}$ were higher than the standard limit $(0.2 \mathrm{mg} / \mathrm{L})$. For cadmium, however, only PBL exceeded the limit stated in regulation. Apart from that, the values of chromium hexavalent for all three landfills fell below the standard limit $(0.05 \mathrm{mg} / \mathrm{L})$. In general, PBL showed the highest reading of heavy metals compared to BPL and ML since the value of lead, copper and cadmium at PBL exceeded the standard limit. The presence of heavy metals in leachate is strongly related to the composition of waste, such as metal based material waste from construction materials, electrical appliances and many more, which releases the heavy metals into the leachate [35]. Heavy metals are also common toxic constituents in some household and office items that are disposed in landfills [36]. Since $\mathrm{pH}$ values increase with the age of the landfill, it reduces metal solubility. With that, the oxidation-reduction process and dissociation of acid will be affected. The heavy metals will react with the hydrogen ion and precipitate in metal hydroxides. At this stage, the stabilized leachate contains less concentration of heavy metal (less than $2 \mathrm{mg} / \mathrm{L}$ ) due to the high $\mathrm{pH}$ value [8].

Table 6. Landfill stability as a function of BOD5/ COD ratio (SWANA, 1997)

\begin{tabular}{cc}
\hline BOD5/COD ratio & Significance \\
\hline$>0.5$ & Young, unstable \\
$0.1-0.5$ & Moderately stable landfill \\
$<0.1$ & Old stable landfill \\
\hline
\end{tabular}

\section{CONCLUSIONS}

Ten parameters of landfill leachate were investigated in this study for three different landfill sites in Peninsular Malaysia to compare its differences based on landfill type and age. In this study, type of landfill such as non sanitary with and without leachate aeration facilities and sanitary landfill has a significant effect on the quality of leachate. Other than that, age of the landfill site also plays an important factor in the quality of leachate production. The older the landfill age, the more stabilize and less pollutant it has. The characteristics of the waste itself very much affect the presence of contaminants in the leachate and can be distributed by physical, chemical and biological processes. The measured parameters also seemed to be affected by climate such as rainfall; and the technology and waste management applied to the landfill. In general, the leachate quality from PBL has the highest range of heavy metals, followed by BPL and ML. This is may due to landfill age, since BPL and ML has been operating longer than PBL.
However, BPL shows greater organic contaminants such as $\mathrm{SS}, \mathrm{BOD}_{5}$ and $\mathrm{COD}$ due to the absence of leachate aeration facilities compared to PBL and ML. Therefore, the implementation of the better and suitable technology for the treatment of landfill leachate should be considered in order to lessen the pollutants before being discharged into our water body system.

\section{ACKNOWLEDGEMENT}

We would like to thank UiTM and Research Acculturation Grant Scheme (RAGS), Ministry of Higher Education for the financial support for this project. Many thanks to Maintenance Unit of the Engineering Department of Tanjung Malim District Council (MDTM), Sabak Bernam District Council (MDSB) and Taiping Municipal Council (MPT).

\section{REFERENCES}

1. Manaf, L.A., M.A.A. Samah, and N.I.M. Zukki, Municipal solid waste management in Malaysia: Practices and challenges. Waste 
Management, 2009. 29(11): p. 2902-2906.

2. McDougall, F.R., et al., Integrated solid waste management: a life cycle inventory. 2008: John Wiley \& Sons.

3. Agamuthu, P. and S. Fauziah, Challenges and issues in moving towards sustainable landfilling in a transitory country-Malaysia. Waste Management \& Research, 2011. 29(1): p. 13-19.

4. Fauziah, S., M. Izzati, and P. Agamuthu, Toxicity on $<i>$ Anabas Testudineus $</ i>$ : A Case Study of Sanitary Landfill Leachate. Procedia Environmental Sciences, 2013. 18: p. 14-19.

5. Aziz, S.Q., et al., Leachate characterization in semi-aerobic and anaerobic sanitary landfills: A comparative study. Journal of environmental management, 2010. 91(12): p. 2608-2614.

6. El-Fadel, M., et al., Temporal variation of leachate quality from pre-sorted and baled municipal solid waste with high organic and moisture content. Waste management, 2002. 22(3): p. 269-282.

7. Baderna, D., et al., A combined approach to investigate the toxicity of an industrial landfill's leachate: Chemical analyses, risk assessment and $<i>$ in vitro $</ i>$ assays. Environmental research, 2011. 111(4): p. 603-613.

8. Kulikowska, D. and E. Klimiuk, The effect of landfill age on municipal leachate composition. Bioresource Technology, 2008. 99(13): p. 5981-5985.

9. Hudgins, M. and S. Harper. Operational characteristics of two aerobic landfill systems. in Proceedings Sardinia. 1999.

10. Regadío, M., et al., Pollution profiles and physicochemical parameters in old uncontrolled landfills. Waste management, 2012. 32(3): p. 482-497.

11. Fauziah, S. and P. Agamuthu, Trends in sustainable landfilling in Malaysia, a developing country. Waste Management \& Research, 2012: p. $0734242 X 12437564$.
12. Andrew, D., et al., Standard methods for the examination of water and wastewater. 2005: American Public Health Association.

13. Rice, E.W.B.L.A.P.H.A.A.W.W.A.W.E.F., Standard methods for the examination of water and wastewater. 2012, Washington, D.C.: American Public Health Association.

14. Zainol, N.A., H.A. Aziz, and M.S. Yusoff, Characterization of Leachate from Kuala Sepetang and Kulim Landfils: A Comparative Study. Energy and Environment Research, 2012. 2(2): p. p45.

15. Zin, M., et al., Characterization of leachate at Matang Landfill site, Perak, Malaysia. Academic Journal of Science, 2012. 1(2): p. 317-322.

16. Zin, N.S.M., et al., A Comparative Study of Matang and Kuala Sembeling Landfills Leachate Characteristics. Applied Mechanics and Materials, 2013.361: p. 776-781.

17. Tränkler, J., et al., Influence of tropical seasonal variations on landfill leachate characteristicsResults from lysimeter studies. Waste Management, 2005. 25(10): p. 1013-1020.

18. Tatsi, A. and A. Zouboulis, A field investigation of the quantity and quality of leachate from a municipal solid waste landfill in a Mediterranean climate (Thessaloniki, Greece). Advances in Environmental Research, 2002. 6(3): p. 207-219.

19. Sanphoti, N., et al., The effects of leachate recirculation with supplemental water addition on methane production and waste decomposition in a simulated tropical landfill. Journal of Environmental Management, 2006. 81(1): p. 27-35.

20. Poznyak, T., et al., Decomposition of toxic pollutants in landfill leachate by ozone after coagulation treatment. Journal of hazardous materials, 2008. 152(3): p. 1108-1114.

21. Renou, S., et al., Landfill leachate treatment: Review and opportunity. Journal of hazardous materials, 2008. 150(3): p. 468-493. 
22. Rafizul, I.M. and M. Alamgir, Characterization and tropical seasonal variation of leachate: Results from landfill lysimeter studied. Waste management, 2012. 32(11): p. 2080-2095.

23. Bashir, M.J., et al., Application of response surface methodology (RSM) for optimization of ammoniacal nitrogen removal from semiaerobic landfill leachate using ion exchange resin. Desalination, 2010. 254(1): p. 154-161.

24. Aziz, H.A., et al., The use of alum, ferric chloride and ferrous sulphate as coagulants in removing suspended solids, colour and COD from semi-aerobic landfill leachate at controlled $\mathrm{pH}$. Waste Management \& Research, 2007. 25(6): p. 556-565.

25. Umar, M., H.A. Aziz, and M.S. Yusoff, Variability of parameters involved in leachate pollution index and determination of LPI from four landfills in Malaysia. International Journal of Chemical Engineering, 2010. 2010.

26. Tchobanoglous, G., H. Theisen, and S. Vigil, Integrated solid waste management: engineering principles and management issues. 1993: McGraw-Hill, Inc.

27. Kubin, A., Landfilling in tropical climates: an analysis of issues to be solved. 2012: na.

28. Ithnin, A., et al., Study on the Effect of Leachates from Old Dumping Site on Water Quality of Sungai Batu in Taman Wahyu II, Selayang, Selangor. Global Journal of Environmental Research, 2012. 6(1): p. 22-29.
29. Lee, A.H., H. Nikraz, and Y.T. Hung, Influence of waste age on landfill leachate quality. International Journal of Environmental Science and Development, 2010. 1(4): p. 347-350.

30. Öman, C.B. and C. Junestedt, Chemical characterization of landfill leachates-400 parameters and compounds. Waste management, 2008. 28(10): p. 1876-1891.

31. Ehrig, H.-J., Quality and quantity of sanitary landfill leachate. Waste Management \& Research, 1983. 1(1): p. 53-68.

32. Tatsi, A., et al., Coagulation-flocculation pretreatment of sanitary landfill leachates. Chemosphere, 2003. 53(7): p. 737-744.

33. Aziz, H.A., et al., Colour removal from landfill leachate by coagulation and flocculation processes. Bioresource Technology, 2007. 98(1): p. 218-220.

34. Christensen, T.H., et al., Biogeochemistry of landfill leachate plumes. Applied geochemistry, 2001. 16(7): p. 659-718.

35. Aziz, H.A., et al., Physico-chemical removal of iron from semi-aerobic landfill leachate by limestone filter. Waste management, 2004. 24(4): p. 353-358.

36. Agamuthu, P., Solid Waste: Principles and Management with Malaysian Case Study. 2001. 